\title{
The impacts of brand experiences on brand loyalty: Mediators of brand love and trust
}

\begin{abstract}
Purpose - 1).Prior studies on brand relationships tend to overlook the mediator(s) between the relationships between brand experience and brand loyalty. Hence, the main purpose of this paper is to examine these mediating roles of brand love and brand trust on the brand experience and brand loyalty relationships. 2). While the literature does not examine the distinct dimensions of brand experience and brand loyalty, this study fills up this gap and examines their detailed dimensions and effects on brand loyalty.

Methodology - A total of 237 valid questionnaires on mobile phone brands were collected from respondents aged between 18 and 30, and analyzed using the partial least squares (PLS) method.

Findings - 1).Sensory experience is the major driver of brand love. 2).Sensory experience mainly drives customers' brand trust, while intellectual experience has no effects on brand trust. 3).Brand love is the main mechanism in developing customers' behavioral loyalty, so does brand trust in shaping their attitudinal loyalty. 4).Brand love and brand trust have the mediating effects on the relationships between brand experience and brand loyalty.

Originality/Value - 1).It demonstrates two mediating roles of brand love and brand trust in the brand experience and brand loyalty relationships, and thus deepens the understanding of the processes in shaping customers' brand loyalty. 2).It departs from the prior works and examines the distinct dimensions of brand experience and brand loyalty, and thus presents a more detailed examination on these two constructs and their effects, than prior studies. 3).It demonstrates the validities of the brand resonance model, the $\mathrm{C}-\mathrm{A}-\mathrm{B}$ and $\mathrm{A}-\mathrm{C}-\mathrm{B}$ models, key mediating variable (KMV) model, particularly in mobile phone industry.
\end{abstract}

Keywords: Brand experience, brand love, brand trust, brand loyalty, brand resonance model, Partial Least Squares (PLS), mobile phone 


\section{The impacts of brand experiences on brand loyalty: Mediators of brand love and trust}

\section{Introduction}

With the increased importance of customer experience, many products and services are designed to create their memorable experiences, such as Apple's iPhone, Body Shop, Harley-Davidson, Disney theme parks and W Hotels (Pine II \& Gilmore, 2011; Schmitt \& Rogers, 2008). Companies' customer acquisition, an important marketing strategy, tends to have its focus from customers' functional benefits, to their experiences on brands. Prior research on customer experience also suggested this important shift from brand benefits to brand experience (Barnes et al., 2014; Dagger and David, 2012; Oliver, 2010; Olsen et al., 2013; Schmitt, 2009; 2013; Vlachos and Tsamakos, 2011). Moreover, customer loyalty, an important concept in marketing, has been demonstrated as an important source of firms' comparative advantages (Auh et al., 2007; Chaudhuri and Holbrook, 2001; Johnson et al., 2006; Kandampully et al., 2015).

Despite the importance of brand experience and customer loyalty, however, rare marketing literature has examined the intermediate mechanisms between the relationships of these two constructs. This study thus fills this gap, and demonstrates two important mediators of brand love and brand trust, on the relationships between brand experience and brand loyalty. This study thus presents a more detailed process model of how and what extent customers develop their brand loyalty, than prior studies (Payne et al., 2008).

In addition, previous research tends to overlook the complexities of brand experience and brand loyalty, by treating them as a single construct (Barkus et al., 2009; Ding \& Tseng, 2015; Olsen et al., 2013; Stokburger-Sauer et al., 2012). This might ignore their distinct, but significant dimensions. This study thus departs from prior works, and tests their specific dimensions, namely, three of brand experience, i.e., sensory, intellectual, behavioral, and two of brand loyalty, i.e., behavioral and attitudinal. Hence, this paper offers a more detailed examination on dimensions of both brand experience and brand loyalty, than prior studies.

To address these important, but under-answered research questions, this study proposes a model, stimulated by brand experience, mediated by brand love and brand trust, and ended with an outcome of brand loyalty, i.e., behavioral and attitudinal. Specifically, this study examines three issues. (1). Do brand experience (i.e., sensory, intellectual, behavioral), and brand love and brand trust, vary in their effects on brand loyalty, i.e., behavioral and attitudinal? (2). Do both brand love and brand trust, exert mediating effects on the relationships between brand experience and brand loyalty? (3). Does brand identification act as a significant moderator on all the relationships of this 
model?

The remaining of this paper is structured as follows. The underlying theory, i.e., the brand resonance model (Keller, 2013; Keller and Richey, 2003), is first introduced, followed by a literature review on the major constructs. The research model and hypotheses are then presented, along with methodology, results, and discussion. Finally, the theoretical and managerial implications, limitations, future research and a conclusion are presented.

\section{Literature review}

In the following section, the literature on the theory, i.e., the brand resonance model (Keller, 2013), as well as the major constructs, are reviewed.

\subsection{The brand resonance model}

The brand resonance model suggests that brand resonance, e.g., brand loyalty, can ultimately be achieved via. two routes, i.e., rational and emotional (Keller, 2013). The rational route includes important components, such as performance (e.g., price, efficiency, durability, reliability), judgment (e.g., quality, credibility), while emotional one includes those, such as imagery and feelings (e.g., fun, excitement) (Keller, 2013). Several reasons facilitate the selection of brand trust and brand love, at each route as the mediators to brand loyalty. Brand love, due to its high-order construct, including complex feelings, thus are appropriate, among emotional factors, as the mediator in this study; while brand trust is demonstrated in prior literature as the important mediator in the brand loyalty model, thus being selected in this study. These two mediators represent the rational and emotional components, respectively, in brand relationship quality (BRQ) (Fournier, 1998). The detailed brand resonance model is portrayed at Appendix 1 .

\subsection{Brand experience}

The concept of brand experience firstly appears in the work of Gilmore and Pine (1999) and Schmitt (1999). This study adopts the definition, proposed by Brakus et al. (2009), that brand experiences are 'subjective, internal consumer responses (sensation, feelings, and cognitions, and behavioral responses), evoked by brand-related stimuli that are part of a brand's design and identity, packaging, communications, and environments' (p.53). It varies in its strength and intensity, and may be either positive or negative, with long effects on consumer behavior (Brakus et al., 2009). Moreover, it is related to, but conceptually distinct from other brand constructs, such as brand attitude, involvement, brand attachment (Brakus et al., 2009; Lane and Jacobson, 1995; Schmitt, 2009; Thomson et al., 2005; Zaichkowsky, 1985).

Brakus et al. (2009) propose four types of brand experiences: sensory, affective, intelligent and behavioral, while Schmitt and Rogers (2008) other five types: sense, feel, think, act and relate. This study adopts Barkus's (2009) three dimensions of sensory, 
intellectual and behavioral, because of the following reasons: 1).These dimensions fit the choice of the context of this study, i.e., young generations who tend to use their mobile phones for these three types of use experiences. 2).Its definitions and measurements are widely used in marketing literature, i.e., better validity and reliability. 3).The affective experience is overlooked in this study because the results show its low validity (Cronbach's alphas $=0.36)$.

\subsection{Mediators: brand love and brand trust}

Brand love is a concept from social psychology. Shimp and Madden (1988) propose the first work by applying Sternberg's (1986) triangular theory of love, while Ahuvia (1993) proposes its first empirical study. Fournier (1998) also suggests that love/passion is an important dimension in BRQ. However, few studies on brand love have been published in marketing journals (Ahuvia, 2005; Albert et al., 2008; Batra et al., 2012; Whang et al., 2004), and this construct still needs its widely-accepted definition and measurements. Hence, brand love, being distinct from satisfaction, liking and trust, is defined as an affection involved with an object in this study (Carroll and Ahuvia, 2006).

Brand trust has been widely studied in relationship marketing, particularly its bridging effects on customers' favorable responses, such as brand loyalty (Chaudhuri and Holbrook, 2001; Laroche et al., 2012; Sirdeshmukh et al., 2002). Drawing from prior literature, brand trust, in this study, is defined as 'feeling of security held by the consumer in his/her interaction with the brand, that it is based on the perceptions that the brand is reliable and responsible for the interests and welfare of the consumer' (Delgado-Ballester, E., et al., 2003).

The main goal of this study is to identity two intermediate mechanisms to brand loyalty. As mentioned, brand love is selected due to its high-order including various types of emotions, while brand trust is due to its importance as a mediator in prior literature.

\subsection{Brand loyalty}

Brand loyalty, in the literature, is realized via. two dimensions. The Stochastic view, proposes that consumers show random behavior in a way that their purchasing behaviors are not a function influenced by prior ones. In contrast, the Deterministic view, suggests that brand loyalty results from the influences of external factors. This view, while interesting, tends to overlook the importance of customers' cognitive processes in shaping brand loyalty (Jacoby and Chestnut, 1978). In light of these, studies of brand loyalty, should not only consider external behaviors, but also the rationales or attitudes consumers hold toward these behaviors (Dick and Basu, 1994; Odin et al., 2001). Hence, this study overcomes the gap of prior research by modeling both behavioral and attitudinal dimensions of brand loyalty (Chaudhuri and Holbrook, 
2001; Jones and Taylor, 2007; Kabiraj and Shanmugan, 2010; Oliver, 1999).

This study defines behavioral loyalty as customers' continuous purchases of a brand, as well as their repeated intention to purchase in the future (Chaudhuri and Holbrook, 2001). Since attitudinal loyalty refers to customers' degree of commitment and their attitude towards the brand, it hence has an emotional component (Chaudhuri and Holbrook, 2001).

\subsection{Brand identification}

Brand identification has been demonstrated as an important construct in brand loyalty model (Bhattacharya and Sen, 2003; Burmann et al., 2009; He et al., 2017; Tuskej et a., 2013). In this study, it refers to 'a consumer's psychological state of perceiving, feeling, and valuing his or her belongingness with a brand' (Lam et al., 2011, p.307). Because brands can transfer symbolic meanings to consumers, they help consumers identify with their actual- and/or ideal-selves (Lam et al., 2011). This study selects brand identification as the moderator because of its importance in brand loyalty literature, thus more suitable, than other constructs, to test the robustness of this proposed model (Lam et al., 2013; Liu et al., 2012; Tuskej et al., 2013).

\section{Research model and hypotheses development}

The brand resonance model offers a solid foundation for this model (Keller, 2013). This model stresses that brand resonance are formulated, started with brand salience, and followed by two routes, i.e., emotional and rational. With this logic, this study proposes that brand loyalty is formulated via. brand salience (i.e., brand experience), and then two mediators (i.e., brand love and brand trust). The research model is shown in Figure 1. 


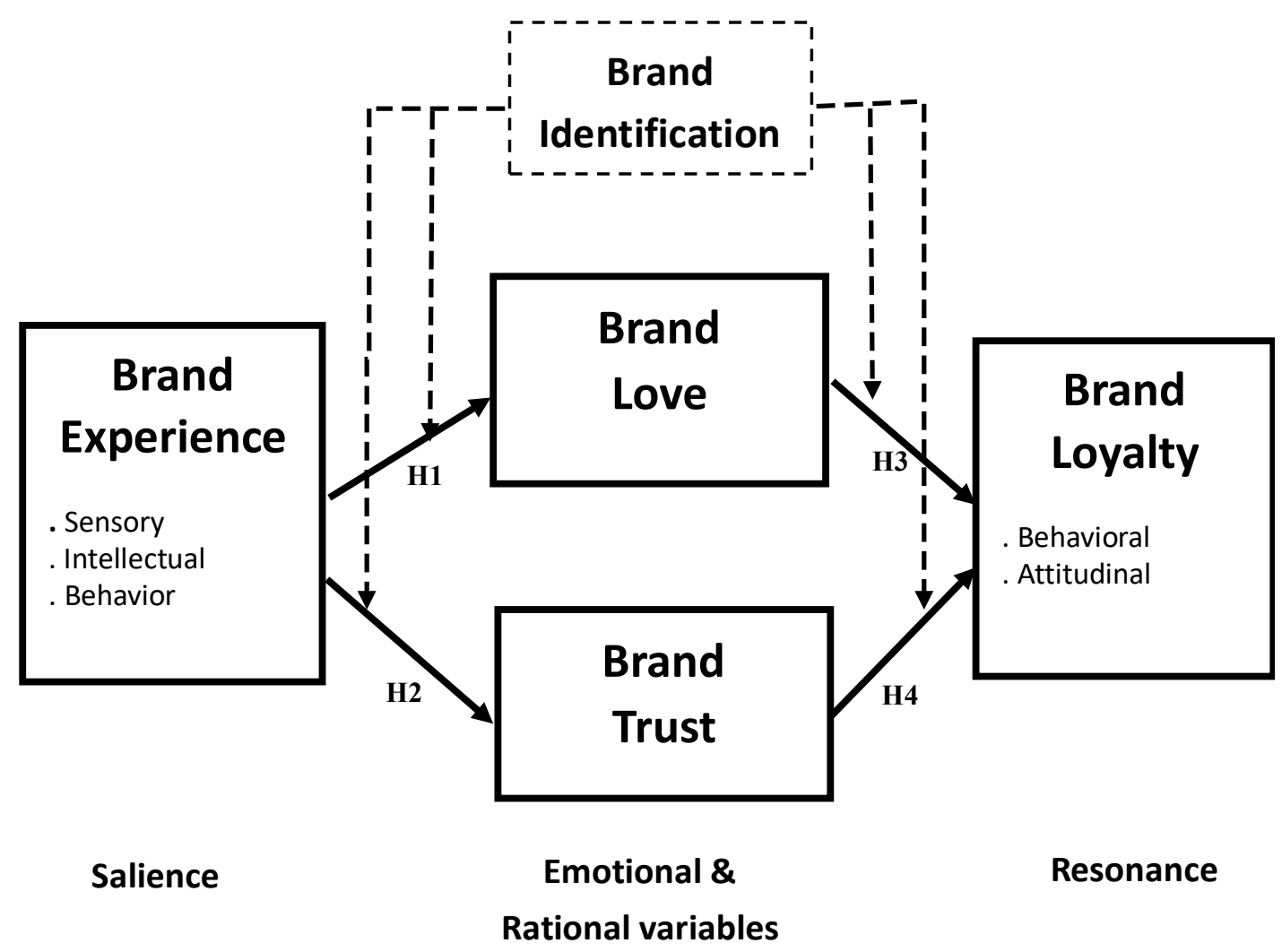

Figure 1. Research model (mediating effects of $\mathrm{H5}$ and $\mathrm{H6}$ are not portrayed here)

\subsection{Brand experience and its effects}

Brand experience, in this study, consists of three elements, i.e., sensory, intellect, behavior, among which, the former two are cognitive responses, while the latter one is behavioral response. Following the rationales of the hierarchy of effects, i.e., the cognition-affection-behavior (C-A-B) model, customers' cognitive responses, e.g., sensory and intellectual experiences, and their behaviors, e.g., behavioral experience, might arose their emotions, e.g., brand love (Breckler, 1984; Solomon, 2014), and thus this study hypothesizes that:

H1a. Sensory experience has positive effects on brand love

$H 1 b$. Intellectual experience has positive effects on brand love.

HIc. Behavioral experience has positive effects on brand love.

Sensory and intellectual experiences are defined as customers' cognitive responses, e.g., to touch, see and know, these two experiences thus have cognitive elements. Related literature has demonstrated the significant antecedents of brands trust, such as functional benefits, actual uses, satisfaction (Delgado-Ballester et al., 2001; 2005; Laroche et al., 2012). As these antecedents have cognitive elements, sensory and intellectual experience, sharing similar elements, might have their effects on brand trust. Behavioral experience, conceptualized as the behavioral interactions and participations 
with the brands, following the hierarchy of effects, i.e., behavioral-cognition-affection (B-C-A) sequence, might has its effects on cognitive responses, such as brand trust (Breckler, 1984; Brakus et al., 2009; Solomon, 2014). Hence, I hypothesize as follows:

$H 2 a$. Sensory experience has positive effects on brand trust

$H 2 b$. Intellectual experience has positive effects on brand trust.

$H 2 c$. Behavioral experience has positive effects on brand trust.

\subsection{Relationships among Brand love, brand trust and brand loyalty}

Brand love consists of many types of emotions, such as passion, positive attitude and evaluation, liking, attachment, commitment and etc. (Albert et al., 2008; Batra et al., 2012; Carroll and Ahuvia, 2006; Shimp and Madden, 1988; Sternberg, 1986). It hence has an emotional component. If consumers love the brand, they might feel greater brand loyalty, desire to use, willingness to invest more resources to purchase the brand, i.e., behavioral loyalty, to be more involved, and to spread positive word-of-mouth (WOM), and attitudinal loyalty (Carroll and Ahuvia, 2006; Batra et al., 2012). Related studies also demonstrate the significant effects of these emotional components, e.g., attachment, on brand loyalty (Aurier and de Lanauze, 2012; Davis-Sramek et al., 2009; Fuchs et al., 2015; Johnson et al., 2006). This study thus extends the effects of these components of brand love on brand loyalty, and thus hypothesizes that:

$H 3 a$. Brand love has positive effects on behavioral loyalty.

$H 3 b$. Brand love has positive effects on attitudinal loyalty.

Brand trust refers to customers' perceptions on whether a brand is reliable and/or responsible for their welfares, it hence has a cognitive element (Delgado-Ballester et al., 2003). From a conceptual viewpoint, if customers feel a sense of security, i.e., trust, on a brand, they might purchase it in the near future or have purchase intention, i.e., behavioral loyalty. Similarly, customers' attitudinal loyalty should develop over time, when their trust on a brand accumulates. Related studies also demonstrate the effects of brand trust on brand loyalty (Ambler, 1997; Chumpitaz and Paparoidamis, 2007; Delgado-Ballester and Munuera-Alemán, 2005; Hur et al., 2014; La and Choi, 2012). This study thus extends the likely influences of brand trust, on brand loyalty's two specific dimensions, and hypothesizes as follows:

$H 4 a$. Brand trust has positive effects on behavioral loyalty.

$H 4 b$. Brand trust has positive effects on attitudinal loyalty

\subsection{The mediating effect of brand love and brand trust}

This study follows the rationales of the brand resonance model, suggesting that customers' resonance, e.g., brand loyalty, could be achieved, started with brand salience (e.g., brand experience), followed by both emotional and rational routes, i.e., brand love 
and trust (Keller, 2013). Moreover, prior studies also suggest the mediating factors of brand love and trust to customers' positive responses, e.g., commitment, self-identity (Delgado-Ballester and Munuera-Alemán, 2001; 2005; Laroche et al., 2012; Loureiro, 2012; Maxian et al., 2013). I thus hypothesize that:

H5.Brand love has mediating effects on the relationships between brand experience and brand loyalty.

H6.Brand trust has mediating effects on the relationships between brand experience and brand loyalty.

\section{Methodology}

\subsection{Data collection}

The main objective of this study is to explore how mobile phone customers respond to firms' customer acquisition strategies with regard to their brand loyalty. Mobile phone brands, such as Apple, Sony, Samsung, Asus, and HTC, are chosen as the research contexts, not only because these brands are so popular with the target customers of this study, i.e., 18-30 years old, but also the current mobile phones are designed to stimulate and satisfy customers' use experiences, rather than their functional needs. In particularly, these brands make great attempts to acquire their customers, by making use of social media (e.g., Twitter), mass media (TV), WOM, as well as to retain their customers by developing customers' brand relationships, such as brand love and brand trust, via. the uses of marketing medias. Mobile phone product is thus an appropriate research context for this study.

The respondents aged between 18 and 30 are chosen because of the following reasons: (1) this group tends to emphasize diversity, lifestyle and brand values more than other groups (Nusair et al., 2011); (2) this group has long been the target of companies aiming to develop brand relationships, and is particularly favored by marketing scholars (Bush et al., 2004).

This study uses the quota sampling technique, drawing from Taiwan's population distribution of 15-30 years old - North (43\%), Central (24.6\%), South and East (32.4\%), and also the gender split of 1: 1 (Ministry of Interior Taiwan, 2016). In total, four universities, i.e., North (two), Central (one) and South (one), are selected to distribute the questionnaires. The respondents show an overall good fit to the general population profile: North (40.9\%), Central (21.5\%), South and East $(37.6 \%)$, and a good gender split of male $(46.4 \%)$ and female $(53.6 \%)$. Data was then collected using a survey instrument, i.e., questionnaire. Respondents were selected averagely at each college of the selected four universities, and then were asked by well-trained interviewers (i.e., face-to-face), to recall a mobile phone brand they bought and used most recently, from a listed 8 options $($ Apple $=1$, Sony Ericsson $=2, H T C=3$, Samsung $=4$, Nokia $=5$, Asus $=6$, Acer $=7$, other $=8$ ). Respondents were asked to base on the brands recalled 
and chosen, and then to complete the questionnaires by choosing the most appropriate answer from the Likert Scale with five end-points, ranging from disagree (1 point) to agree (5 points). Finally, of the total of 332 collected questionnaires, 237 (71.3\%) are valid for further analysis. Therefore, this study has its control variables on each construct: age, ranging from 18 to 30, income level from USD 0 to 2258, and gender and area, following Taiwan's population distribution. Table I shows the details of respondents' portfolio, as follows.

Table I. Respondents' portfolio of this study

\begin{tabular}{|c|c|c|c|c|}
\hline Descriptors & Sub-descriptors & $\begin{array}{c}\text { Frequency } \\
(\mathbf{n}=\mathbf{2 3 7})\end{array}$ & Percentage & Accumulated \% \\
\hline \multirow[t]{2}{*}{ Gender } & Male & 110 & $46.4 \%$ & $46.4 \%$ \\
\hline & Female & 127 & $53.6 \%$ & $100.0 \%$ \\
\hline \multirow[t]{2}{*}{ Age } & $18-22$ & 168 & $70.9 \%$ & $70.9 \%$ \\
\hline & $23-30$ & 69 & $29.1 \%$ & $100.0 \%$ \\
\hline \multirow[t]{5}{*}{ Occupation } & Undergraduate & 185 & $78.1 \%$ & $78.1 \%$ \\
\hline & Graduate & 25 & $10.5 \%$ & $88.6 \%$ \\
\hline & Staff & 18 & $7.6 \%$ & $96.2 \%$ \\
\hline & Manager & 6 & $2.5 \%$ & $98.7 \%$ \\
\hline & Other & 3 & $1.2 \%$ & $100.0 \%$ \\
\hline \multirow[t]{3}{*}{ Education } & College & 132 & $55.7 \%$ & $55.7 \%$ \\
\hline & University & 92 & $38.4 \%$ & $94.1 \%$ \\
\hline & Graduate school & 14 & $5.9 \%$ & $100.0 \%$ \\
\hline Average & No income & 73 & $30.8 \%$ & $30.8 \%$ \\
\hline monthly income & $\leqq 323$ & 67 & $28.3 \%$ & $59.1 \%$ \\
\hline \multirow[t]{3}{*}{ (USD) } & $324 \sim 968$ & 75 & $31.6 \%$ & $90.7 \%$ \\
\hline & $969 \sim 1613$ & 16 & $6.8 \%$ & $97.4 \%$ \\
\hline & $1614 \sim 2258$ & 4 & $1.6 \%$ & $100.0 \%$ \\
\hline \multirow[t]{3}{*}{ Location } & North & 97 & $40.9 \%$ & $40.9 \%$ \\
\hline & Central & 51 & $21.5 \%$ & $62.4 \%$ \\
\hline & South \& East & 89 & $37.6 \%$ & $100.0 \%$ \\
\hline
\end{tabular}

\subsection{Measurement scales}

The measurement scales of each construct are adapted from previous studies, i.e., brand experience (sensory, intellectual, and behavioral) (Brakus et al., 2009), brand love (Carroll and Ahuvia, 2006), brand trust (fiability and intentionality) (DelgadoBallester, E., et al., 2003), brand loyalty (attitudinal and behavioral) (Chaudhuri and Holbrook, 2001) and brand identification (Lam et al., 2011). All these scales were originally written in English, and then translated into Mandarin. Each item was assessed 
using a five-point Likert scale with endpoints of 'strongly disagree (=1)' and 'strongly agree (=5)'. Appendix 2 shows the details of this study's measurements.

\subsection{Data analysis}

All the measurements of this study are collected from a single questionnaire, and this might result in the common method variance (CMV) problem (Podsakoff et al., 2003). In order to avoid this risk of CMV, this study uses the Harmon's one factor test, which proposes that if the CMV problem exists, a dominant single factor might emerge (Podsakoff and Organ, 1986). The results show that no dominant factor emerges in the factor analysis using SPSS, and the greatest factor only explains 35.5\% of the total variances, and thus this study is free of the CMV issue.

Prior to the partial least squares (PLS) analysis, the exploratory factor analysis (EFA) was conducted on 166 valid questionnaires, using SPSS 20.0 to identify invalid items with factor loadings $(<0.6)$, which were then deleted for better convergent validity and reliability. A valid factor should have an eigenvalue of greater than 1 , total variance greater than $5 \%$, and an accumulated total variance greater than $50 \%$ (Hair et al., 2010).

This study used principle-component analysis with varimax rotation. Specifically, all items were kept from other three experiences; items 2, 3, 4, and 7 were deleted from brand love and 2 items from brand trust; item 2 was away from both attitudinal behavioral loyalty and finally 3 items were taken away from brand identification. In total, of the 42 initial items, 31 items were remained for structural equation modeling (SEM) analysis using PLS method. More specifically, SmartPLS 2.0 was used to test the hypotheses. The vector of parameter estimates, such as Cronbach's alphas (CA), average variance extracted (AVE), $\beta$ values, $t$ statistics and CV redundancy $\mathrm{Q}^{2}$ values, were obtained by running functions of PLS, Bootstrapping for 2000 times, and Blindfolding.

PLS is a variance-based structural modeling technique, developed by Wold (1974), and used in this study for the following reasons: (1).The aim of this study is to predict the relationships among multiple latent variables, rather than to confirm a particular theory (Hair et al., 2011; Hair, Sarstedt et al., 2012; Vinzi et al., 2010); (2).It is a multivariate path modeling method, typically used to predict multiple independent and dependent latent variables (Hair et al., 2014; Mathwick et al., 2008). (3).Covariancebased structural equation modeling, such as LISREL, requires multivariate data normality and a larger sample size, but PLS does not. (Barroso et al., 2010; Hair et al., 2011 ; 2014). This is a predictive study with multiple latent IVs and DVs, particularly a smaller sample size $(\mathrm{N}=237)$, thus PLS method is appropriate (O'Loughlin and Coenders, 2004; Ringle et al., 2005).

\section{Results}

\subsection{Measurement model}


As shown in Table II, the means, standard deviations, Cronbach's alphas (CA), average variance extracted (AVE), and correlation matrix are presented. The Cronbach's alphas, ranging from 0.73 to 0.86 , exceed the threshold $(>0.7)$. The composite reliabilities, ranging from 0.84 to 0.89 , and average variance extracted (AVE), ranging from 0.50 to 0.69 , show values above the thresholds of composite reliability (CR) $\square 0.7$ (Nunnally, 1978), AVE $\square 0.5$ (Fornell and Lacker, 1981). The measurement model thus has high reliability and convergent validity. This study evaluates discriminant validity by using Fornell and Lacker's (1981) test of shared variance between pairs of latent constructs. The results demonstrate that the squared correlations between each pair of constructs do not exceed the AVE of a single construct, which confirms the model's discriminant validity. In order to reconfirm the robustness and stability of this model, the goodness of fit value (Chin, 2010; Fornell and Lacker, 1981), corss-validated $(\mathrm{CV})$ redundancy $\mathrm{Q}^{2}$ and $\mathrm{CV}$ communality $\mathrm{Q}^{2}$ tests (omission distance $=3$ ) using the blindfolding function in SmartPLS 2.0 are calculated. The results show that the GoF value of 0.52 exceeds the threshold value of 0.27 (Fornell and Lacker, 1981), confirming an excellent fit of the model to the data. In addition, the values of $\mathrm{CV}$ redundancy $\mathrm{Q}^{2}$, ranging from 0.15 to 0.71 , and those of $\mathrm{CV}$ communality $\mathrm{Q}^{2}$, ranging from 0.36 to 0.71 , all exceed the threshold value of 0 , and thus reconfirm the cross-validity of this model (Hair et al., 2014).

Table II. Descriptive statistics, Average Variance Extracted (AVE) and Correlation matrix

\begin{tabular}{|c|c|c|c|c|c|c|c|c|c|c|c|c|}
\hline & Mean & SD & $\alpha$ & CR & AVE & 1 & 2 & 3 & 4 & 5 & 6 & 7 \\
\hline (Threshold) & & & $>0.7$ & $\geqq 0.7$ & $\geqq 0.5$ & & & & & & & \\
\hline Sensory experience & 3.60 & 0.67 & 0.74 & 0.85 & 0.66 & 0.81 & & & & & & \\
\hline Intellectual experience & 3.45 & 0.63 & 0.73 & 0.85 & 0.65 & 0.40 & 0.81 & & & & & \\
\hline Behavioral experience & 3.23 & 0.62 & 0.78 & 0.87 & 0.69 & 0.35 & 0.48 & 0.83 & & & & \\
\hline Brand love & 3.49 & 0.63 & 0.85 & 0.89 & 0.63 & 0.53 & 0.45 & 0.41 & 0.79 & & & \\
\hline Brand trust & 3.40 & 0.64 & 0.86 & 0.89 & 0.50 & 0.50 & 0.39 & 0.42 & 0.63 & 0.71 & & \\
\hline Behavioral loyalty & 3.43 & 0.72 & 0.77 & 0.87 & 0.68 & 0.48 & 0.40 & 0.40 & 0.59 & 0.56 & 0.82 & \\
\hline Attitudinal loyalty & 3.54 & 0.72 & 0.73 & 0.84 & 0.64 & 0.50 & 0.38 & 0.38 & 0.59 & 0.60 & 0.80 & 0.80 \\
\hline
\end{tabular}

Notes: SD = standard deviation; $\alpha=$ Cronbach's Alpha; $\mathrm{CR}=$ Composite reliability; AVE = average variance extracted; Diagonal items $=\sqrt{ } \mathrm{AVE}$

\subsection{Structural model}

\subsubsection{Main effects}

As shown in Figure 2, brand experience, in total, explains approximately $37.0 \%$ $\left(\mathrm{R}^{2}=0.37\right)$ of brand love, showing its excellent explanatory power. More specifically, sensory, intellectual and behavioral experiences, all have positive effects on brand love $(\beta=0.39, t=5.49 ; \beta=0.20, t=3.05 ; \beta=0.18, t=2.79)$, thus supporting H1a H1c. These results demonstrate that brand experience is an important antecedent of brand 
love, because of its strong explaining power $\left(\mathrm{R}^{2}=0.37\right)$, particularly sensory experience, exerting its strongest effects among three experiences $(\beta=0.39, t=5.49)$.

Moreover, three brand experiences all together explain $34.0 \%$ of brand trust $\left(\mathrm{R}^{2}=\right.$ $0.34)$, showing its good explanatory power. More specifically, both sensory and behavioral experiences have positive influences on brand trust $(\beta=0.37, t=6.12 ; \beta=$ $0.23, t=2.68$ ), thus supporting $\mathrm{H} 2 \mathrm{a}$ and $\mathrm{H} 2 \mathrm{c}$; however, intellectual experiences have no effects on brand trust $(\beta=0.13, t=1.46)$, and thus $\mathrm{H} 2 \mathrm{~b}$ are rejected. These results show that both sensory and behavioral experiences are important drivers of brand trust in shaping customers' loyalty toward their brands, but intellectual one is not.

Brand love and brand trust together explain $41 \%$ of behavioral loyalty $\left(\mathrm{R}^{2}=0.41\right)$, and thus show their good explaining power, particularly brand love, with its stronger positive effect ( $\beta=0.39, t=4.97)$, than brand trust $(\beta=0.31, t=4.35)$ on behavioral loyalty. These results demonstrate that brand love is a more important antecedent, than brand trust, in driving customers' behavioral attitude, thus supporting H3a and H4a. Attitudinal loyalty is also well explained $\left(\mathrm{R}^{2}=0.44\right)$ by brand love and brand trust. However, brand trust has stronger effects $(\beta=0.39, t=5.36)$, than brand love $(\beta=0.35$, $t=4.39$ ), on attitudinal loyalty. These findings suggest that brand trust plays a major role than brand love, in driving customers' long-term attitudinal loyalty, in a way that supports $\mathrm{H} 3 \mathrm{~b}$ and $\mathrm{H} 4 \mathrm{~b}$.

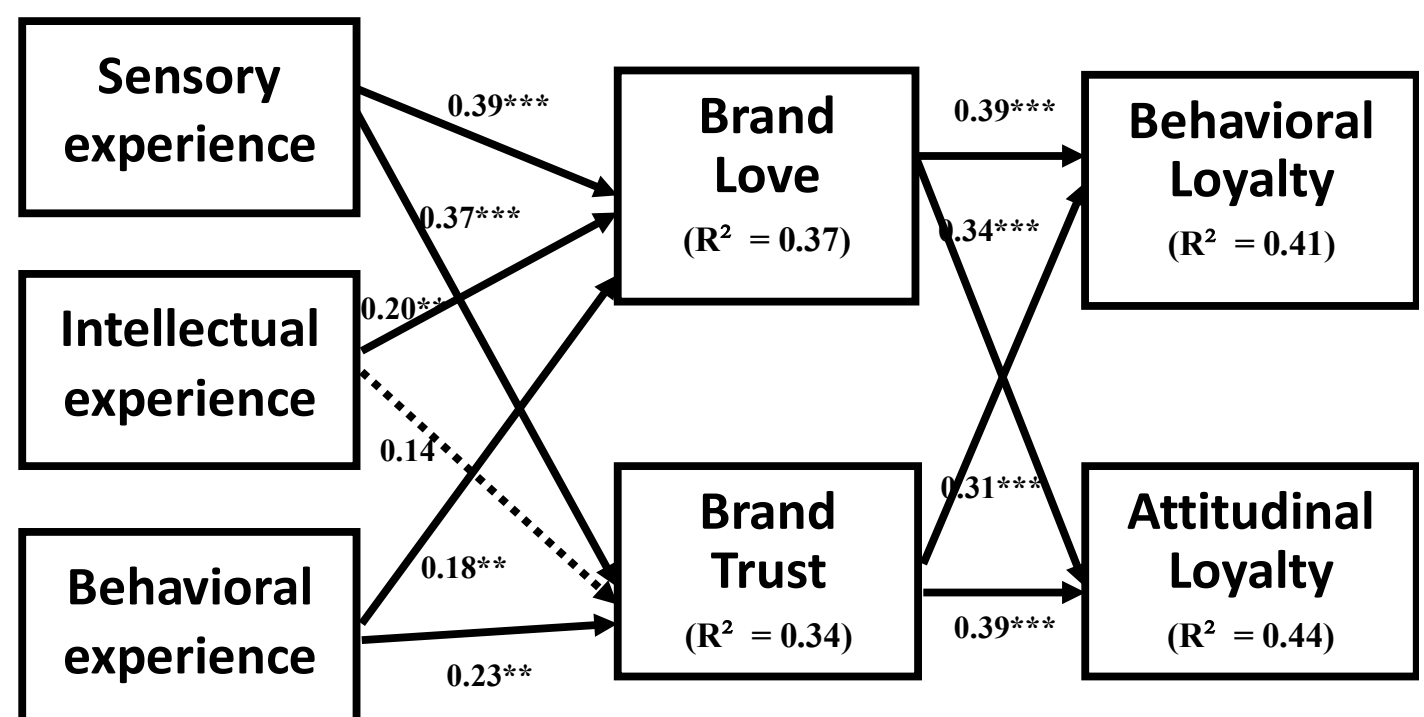

Figure 2. Results of main effects

Notes: Significant at $* \mathrm{p}<0.05 ; * * \mathrm{p}<0.01 ; * * * \mathrm{p}<0.005$

The dotted line represents non-significant effect

\subsubsection{Mediating effects of brand love and brand trust}

In order to test the mediating effects of both brand love and brand trust between 
the relationships of brand experience and brand loyalty, the method proposed by Baron and Kenny (1986) is used to test four competing models. As presented in more details at Appendix 2, Model 1 shows that all independent variables (IVs), i.e., brand experiences have positive effects on the mediators, i.e., brand love and trust, except for the effects of intellectual experiences on brand trust. Model 2 indicates that only sensory and intellectual experiences have positive effects on dependent variables (DVs), i.e., behavioral and attitudinal loyalty. Model 3 shows that all mediators have positive influences on DVs. Model 4 clearly shows that none of the IVs have significant effects on the DVs, when the mediators, i.e., brand love and brand trust, are treated as IVs, except for sensory experience, still exerting its significant effects on both behavioral and attitudinal loyalty. These findings conclude that both brand love and trust have full mediating effects on the relationships between behavioral experience and brand loyalty, i.e., behavioral and attitudinal loyalty. Both brand love and trust have no mediating effects when the powerful sensory experience is stimulated. The detailed results are presented at Table III as follows, and the results of four competing models are tabulated at Appendix 3.

Table III: Results of mediating effects of brand love and brand trust

\begin{tabular}{lll}
\hline Mediators & \multicolumn{1}{c}{ Paths } & Mediating effects \\
\hline Brand love & Sensory experience $\rightarrow$ Brand love $\rightarrow$ Behavioral loyalty & Non-significant \\
& Intellectual experience $\rightarrow$ Brand love $\rightarrow$ Behavioral loyalty & Partial mediation \\
& Behavioral experience $\rightarrow$ Brand love $\rightarrow$ Behavioral loyalty & Full mediation \\
& Sensory experience $\rightarrow$ Brand love $\rightarrow$ Attitudinal loyalty & Non-significant \\
& Intellectual experience $\rightarrow$ Brand love $\rightarrow$ Attitudinal loyalty & Partial mediation \\
& Behavioral experience $\rightarrow$ Brand love $\rightarrow$ Attitudinal loyalty & Full mediation \\
Brand trust & Sensory experience $\rightarrow$ Brand trust $\rightarrow$ Behavioral loyalty & Non-significant \\
& Intellectual experience $\rightarrow$ Brand trust $\rightarrow$ Behavioral loyalty & Non-significant \\
& Behavioral experience $\rightarrow$ Brand trust $\rightarrow$ Behavioral loyalty & Full mediation \\
& Sensory experience $\rightarrow$ Brand trust $\rightarrow$ Attitudinal loyalty & Partial mediation \\
& Intellectual experience $\rightarrow$ Brand trust $\rightarrow$ Attitudinal loyalty & Non-significant \\
& Behavioral experience $\rightarrow$ Brand trust $\rightarrow$ Attitudinal loyalty & Full mediation \\
\hline
\end{tabular}

\subsubsection{Moderating effects of brand identification}

In order to test the stability of this model, this study chooses brand identification as a potential moderator, and further tests its effects on the relationships of this study, using moderating effect function in the SmartPLS 2.0. The results clearly show that none of those paths are significantly moderated by brand identification, and thus reconfirm the stability and robustness of the proposed model. The detailed results are tabulated at Table IV, as follows. 
Table IV Results of moderating effects of brand identification

\begin{tabular}{llcl}
\hline \multicolumn{1}{c}{ Moderating effects } & $\begin{array}{c}\text { Path } \\
\text { coefficients }\end{array}$ & t-value & Results \\
\hline (Threshold value) & & $(\geqq \mathbf{1 . 9 6 )}$ & \\
Sensory experience $\rightarrow$ Brand love & -0.48 & 0.79 & Non-significant \\
Intellectual experience $\rightarrow$ Brand love & 0.12 & 0.28 & Non-significant \\
Behavioral experience $\rightarrow$ Brand love & 0.22 & 0.31 & Non-significant \\
Sensory experience $\rightarrow$ Brand trust & -0.37 & 0.69 & Non-significant \\
Intellectual experience $\rightarrow$ Brand trust & -0.12 & 0.16 & Non-significant \\
Behavioral experience $\rightarrow$ Brand trust & 1.18 & 1.93 & Non-significant \\
Brand love $\rightarrow$ Behavioral loyalty & -0.99 & 1.27 & Non-significant \\
Brand love $\rightarrow$ Attitudinal loyalty & -1.10 & 1.78 & Non-significant \\
Brand trust $\rightarrow$ Behavioral loyalty & 0.74 & 0.96 & Non-significant \\
Brand trust $\rightarrow$ Attitudinal loyalty & 0.53 & 0.83 & Non-significant \\
\hline
\end{tabular}

Notes: Significant at $* \mathrm{p}<0.05 ; * * \mathrm{p}<0.01 ; * * * \mathrm{p}<0.005$

\section{Discussion}

This study concludes with the following findings. First, sensory experience is the major driver of brand love. Second, sensory experience mainly drives customers' brand trust, while intellectual experience has no effects on brand trust. Third, brand love is the main mechanism in developing customers' behavioral loyalty, so does brand trust in shaping their attitudinal loyalty Most importantly, this study also finds that brand love and brand trust have the mediating effects on the relationships between brand experience and brand loyalty. Finally, brand identification does not significantly moderate all the relationships in this proposed model.

The finding that sensory experience is the main driver of brand love, to my best knowledge, could rarely be found in prior marketing literature, though some might have discussed the relationships between brand experience and emotional responses (Ding and Tseng, 2015; Stokburger-Sauer, 2012; ). A partial explanation might be that sensory response has a cognitive component, thus having the greatest shorter-term psychological reactions, such as brand love, which, in this study, is defined as a shortterm romantic passion.

This study also finds that sensory experience plays a major role in shaping brand trust. To date, little literature has reported this result, however, with the majority identifying its antecedents, such as satisfaction, functional and symbolic benefits (Ha and Perks, 2005; Laroche et al., 2012; Sirdeshmukh et al., 2002; Zboja and Voorheas, 2006). This finding thus departs from prior works, and proposes a more detailed dimension of brand experience, i.e., sensory experience, in driving customers' trust on 
brands.

The finding that brand love the main driver of behavioral loyalty is a new insight in the literature. This result is out of my expectation. A possibility might be that brand love, defined as the short-term romantic passion in this study, might result in short-term responses, i.e., behavioral loyalty. This study thus offers an important insight that brand love, defined as a short-term romantic emotion, directly drives the short-term behavioral loyalty, such as purchase.

Another finding that brand trust is a major antecedent in shaping customers' attitudinal loyalty, echoes those found in prior literature (Ha and Perks, 2005; Laroche et al., 2012; Sirdeshmukh et al., 2002; Zboja and Voorheas, 2006). Much related work has demonstrated the focal role of brand trust to brand loyalty (Ha and Perks, 2005; Delgado-Ballester and Munuera-Alemán, 2001). This might be well explained by the long-term characteristics of both brand trust and attitudinal loyalty. This finding thus offers an important insight that brand trust, requiring long-term development, might mostly drive customers' attitudinal loyalty.

This study also demonstrates the mediating effects of brand love and trust. Prior works rarely report these roles of brand love and trust in the brand experience and loyalty relationships, though brand trust has been identified as the linking, but not mediating role, in previous studies (Ha and Perks, 2005; Delgado-Ballester and Munuera-Alemán, 2001)). This study hence proposes a new brand loyalty model, initiated by brand experience, mediated by brand love and trust, and thus contributes to the literature by deepening the understanding of the process in shaping brand loyalty, than prior works.

\subsection{Theoretical implications}

Keller (2013) proposes the brand resonance model, suggesting a rational and an emotional routes to brand resonance. This study echoes with this model, and further demonstrates the validity of the brand resonance model, by identifying the mediating roles of brand love, i.e., emotional route, and brand trust, i.e., rational one, to brand loyalty, particularly in mobile-phone products.

The cognition-affection-behavior (C-A-B) and A-C-B models suggests that cognition, affection and behavior, are three correlated, but distinct components of attitude, and also that customers' attitude are developed via. these sequences (Breckler, 1984; Holbrook and Batra, 1987; Solomon, 2014). This finding thus confirms both the C-A-B and A-C-B models (Breckler, 1984), and the experiential hierarchy of effects (Holbrook and Hirschman, 1982; Solomon, 2014), by identifying the mediating roles of brand love, i.e., affection(A), and brand trust, i.e., cognition(C), particularly in mobile phone products.

The key mediating variable (KMV) model, proposed by Morgan and Hunt (1994), 
and the process model of Payne (2008), suggest that trust and commitment play the central roles to brand loyalty. This paper thus extends the validity of these two models, by suggesting two important mediating roles of brand love and trust, from a B-B to a B-C context, i.e., mobile phones.

The bridging strategy, proposed by Harrison-Walker and Coopett (2003), suggests two bridges to a firm's success. This study thus demonstrates two complementary bridges, i.e., brand love, and brand trust, in shaping customers' brand loyalty, particularly in mobile phone industry. Moreover, Fournier (1998) proposes the concept of brand relationship quality (BRQ), such as love, self-connection, commitment, partner, and suggests that BRQ is a means to an end, i.e., a process component to brand loyalty (Fournier et al., 2015). This study thus extends the validity of BRQ model, by elucidating two important BRQs, i.e., brand love and trust, particularly in mobile phone industry.

\subsection{Managerial implications}

This study offers managerial solutions to develop customer acquisition and loyalty strategies, particularly in mobile phone industry. Companies aiming to achieve behavioral loyalty should adopt sensory marketing strategies (i.e., see, feel, touch, smell, listen), via. brand love, while those targeting at their attitudinal loyalty are advised to use the similar strategy, i.e., sensory marketing, however, via brand trust. In practice, this could be done, for example, by designing a fancy and fashionable product outlook to build customers' brand love, and by equipping the mobile phones with a reliable product function to develop their brand trust.

Alternatively, companies might shape customers' behavioral loyalty, using either behavioral or intellectual marketing strategies, via. brand love, and to develop their attitudinal loyalty via. behavioral experience and then brand trust. These could be implemented by making good use of tailor-made social media, such as WeChat, Line, Facebook, on-line games, to create customers' interactions and participations.

This study also demonstrates the mediating effects of brand love and brand trust. Hence, companies are advised to maintain sound brand love and trust relationships, under different customer acquisition strategies. As brand love is the more important mediator than brand trust, thus companies should adopt diverse bridging strategies, for example, TV commercials, rather than stable product functions alone, to build brand loyalty (Harrison-Walker and Coppott, 2003).

\subsection{Limitations and further research}

This study should be considered for its limitations. First, this research does not strictly follow the standards of multivariate normality, for example, Taiwan's geographical and gender distribution, although the control variables, e.g., gender, education, incomes, have been used in this study. Future studies thus should follow the 
stricter standard of multivariate normality, and examine other sample segments other than this study. Second, brand love, in this study, is defined as the short-term emotion (Carroll and Ahuvia, 2006), however, it is a higher-order construct with multiple and complex emotions (Albert et al., 2009; Bagozzi et al., 2016; Batra et al., 2012). Studies in the future should examine its specific dimensions, such as passion driven behavior, long-term relationship (Batra et al., 2012). Third, this study does not examine the affective experience due to its low factor loadings and Cronbach's alphas, i.e., insignificant validity. Hence, further studies should develop a more valid and reliable measurement, in order to really examine this construct. Lastly, this study only tests the mediating roles of brand love and trust, not other factors. The brand resonance model suggests other possible variables, such as brand attachment, brand community, engagement, and product efficiency, and thus further studies might use these important factors as the mediators (Keller, 2013).

\section{Conclusions}

Despite this study's limitations, it makes the following contributions. First, it demonstrates two mediating roles of brand love and brand trust in the brand experience and brand loyalty relationships, and thus deepens the understanding of the processes in shaping customers' brand loyalty, particularly in mobile phone industry. Second, this study departs from the prior works, and examines the distinct dimensions of brand experience and brand loyalty, and thus presents a more detailed examination on these two constructs and their effects, than prior studies. Third, it demonstrates the validities of the brand resonance model (Keller, 2013), the C-A-B and A-C-B models (Breckler, 1984; Solomon, 2014), key mediating variable (KMV) model (Morgan and Hunt, 1994), particularly in mobile phone industry. 


\section{References}

Ahuvia, A.C. (1993), "I love it! towards a unifying theory of love across diverse love objects", Unpublished PhD dissertation, Northwestern University, Chicago, USA.

Ahuvia, A.C. (2005), “Beyond the extended self: loved objects and consumers' identity narratives", Journal of Consumer Research, Vol. 32, No. 1, pp. 171-184.

Albert, N., Merunka, D.and Valette-Florence, P. (2008), "When consumers love their brands: exploring the concept and its dimensions", Journal of Business Research, Vol. 61, No. 10, pp. 1062-1075.

Albert, N., Merunka, D. and Valette-Florence, P. (2009), "The feeling of love toward a brand: Concept and measurement". Advances in Consumer Research, Vol. 36, pp. 300-307.

Ambler, T. (1997), “Do brands benefit consumers?". International Journal of Advertising, Vol. 16, No. 3, pp. 167-195.

Auh, S., Bell, S. J., McLeod, C. S. and Shih, E. (2007), "Co-production and customer loyalty in financial services", Journal of Retailing, Vol. 83, No. 3, pp. 359-370.

Aurier, P. and de Lanauze, G.S. (2012), "Impacts of perceived brand relationship orientation on attitudinal loyalty: an application to strong brands in the packaged goods sector”, European Journal of Marketing, Vol. 46, No. 11/12, pp. 8-18.

Bagozzi, R.P., Batra, R. and Ahuvia, A. (2016), "Brand love: development and validation of a practical scale", Marketing Letters, Vol. 28, No. 1, pp. 1-14.

Brakus, J., Schmitt, B. and Zarantonello, L. (2009), "Brand experience: what is it? how is it measured? does it affect loyalty?", Journal of Marketing, Vol. 73, No. 3, pp. 52-68.

Barnes, S.J., Mattsson, J. and Sørensen, F.(2014), "Destination brand experience and visitor behavior: testing a scale in the tourism context", Annals of Tourism Research, Vol. 48, pp. 121-139.

Baron, R.M. and Kenny, D.A. (1986), “The moderator-mediator variable distinction in social psychological research: conceptual, strategic, and statistical considerations". Journal of Personality and Social Psychology, Vo. 51, No. 6, pp. 1173-1182.

Barroso, C., Carrión, G.C.and Roldán, J.L. (2010), “Applying maximum likelihood and PLS on different sample sizes: studies on SERVQUAL model and employee behavior model", in V. E. Vinzi, et al. (eds.), Handbook of Partial Least Squares: Concepts, Methods and Applications, Springer, New York, pp. 427-447.

Batra, R., Ahuvia, A. and Bagozzi, R.P. (2012), "Brand love", Journal of Marketing, Vol. 76, No. 1, pp. 1-16.

Bhattacharya, C. B. and Sen, S. (2003), "Consumer-company identification: a 
framework for understanding consumers' relationships with companies". Journal of Marketing, Vol. 67, No. 2, pp. 76-88.

Brakus, J., Schmitt, B.and Zarantonello, L. (2009), "Brand experience: what is it? how is it measured? does it affect loyalty?", Journal of Marketing, Vol. 73, No. 3, pp. $52-68$.

Breckler, S. J. (1984), "Empirical validation of affect, behavior, and cognition as distinct components of attitude". Journal of Personality and Social Psychology, Vol. 47, No. 6, pp. 1191-1205.

Burmann, C., Jost-Benz, M. and Riley, N. (2009), "Towards an identity-based brand equity model”. Journal of Business Research, Vol. 62, No. 3, pp. 390-397.

Bush, A.J., Martin, C.A.and Bush, V.D. (2004), "Sports celebrity influence on the behavioral intentions of Generation Y", Journal of Advertising Research, Vol. 44, No. 1, pp. 108-118.

Carroll, B.A. and Ahuvia, A.C. (2006), "Some antecedents and outcomes of brand love", Marketing Letters, Vol. 17, No. 2, pp. 79-89.

Chaudhuri, A. and Holbrook, M.B. (2001), "The chain of effects from brand trust and brand affect to brand performance: the role of brand loyalty", Journal of Marketing, Vol. 65, No. 2, pp. 81-93.

Chin, W.W. (2010). How to Write Up and Report PLS Analyses, Handbook of Partial Least Squares: Concepts, Methods and Applications (pp. 655-690), Springer, New York.

Chumpitaz Caceres, R., \& Paparoidamis, N. G. (2007), "Service quality, relationship satisfaction, trust, commitment and business-to-business loyalty". European Journal of Marketing, Vol. 41, No. (7/8), pp. 836-867.

Dagger, T.S. and David, M.E.(2012), "Uncovering the real effect of switching costs on the satisfaction-loyalty association: the critical role of involvement and relationship benefits"', European Journal of Marketing, Vol. 46, No. 3/4, pp. 447-468.

Davis-Sramek, B., Droge, C., Mentzer, J.T. and Myers, M.B.(2009), "Creating commitment and loyalty behavior among retailers: what are the roles of service quality and satisfaction?", Journal of the Academy of Marketing Science, Vol. 37, No. 4, pp. 440-454.

Delgado-Ballester, E. and Munuera-Alemán, J.L. (2001), "Brand trust in the context of consumer loyalty", European Journal of Marketing, Vol. 35, No. 11/12, pp. 1238-1258.

Delgado-Ballester, E., \& Munuera-Alemán, J. L. (2005), “Does brand trust matter to brand equity?" Journal of Product \& Brand Management, Vol. 14, No. 3, pp. 187-196. 
Delgado-Ballester, E., Munuera-Aleman, J.L. and Yague-Guillen, M.J. (2003), "Development and validation of a brand trust scale",International Journal of Market Research, Vol. 45, No. 1, pp. 35-54.

Dick, A.S. and Basu, K. (1994), "Customer loyalty: toward an integrated conceptual framework". Journal of the Academy of Marketing Science, Vol. 22, No. 2, pp. 99-113.

Ding, C.G. and Tseng, T.H.(2015), "On the relationships among brand experience, hedonic emotions, and brand equity", European Journal of Marketing, Vol. 49, No. 7/8, pp. 994-1015.

Fornell, C. and Lacker, D. (1981), "Evaluating structrual equation model with unobservable variable and meaurement error", Journal of Martketing Research, Vol. 18, No. 1, pp. 39-50.

Fournier, S. (1998), "Consumers and their brands: developing relationship theory in consumer research", Journal of Consumer Research, Vol. 24, No. 4, pp. 343353.

Fournier, S., Breazeale, M. and Avery, J. (2015). Strong Brands, Strong Relationships, Routledge, New York.

Fuchs, C., Schreier, M. and Van Osselaer, S.M.(2015), "The handmade effect: what's love got to do with it?", Journal of Marketing, Vol. 79, No. 2, pp. 98-110.

Gilmore, J. and Pine, J. (1999), "The Experience Economy: Work is Theatre and Every Business a Stage”, Harvard Business Publ., Cambridge, Massachusetts, USA.

Ha, H.Y. and Perks, H. (2005), "Effects of consumer perceptions of brand experience on the web: brand familiarity, satisfaction and brand trust". Journal of Consumer Behaviour, Vol. 4, No. 6, pp. 438-452.

Hair, J.F., Black, W.C., Babin, B.J., Anderson, R.E. and Tatham, R.L. (2010), Multivariate Data Analysis, Upper Saddle River, Pearson, New Jersey.

Hair, J.F., Ringle, C.M.and Sarstedt, M. (2011), "PLS-SEM: indeed a silver bullet", Journal of Marketing Theory and Practice, Vol. 19, No. 2, pp. 139-152.

Hair Jr, J. F., Hult, G. T. M., Ringle, C. M. and Sarstedt, M. (2014). A Prime on Partial Least Squares Structural Equation Modeling (PLS-SEM). Thousand Oaks, California: Sage.

Hair, J.F., Sarstedt, M., Ringle, C.M. and Mena, J.A.(2012), “An assessment of the use of partial least squares structural equation modeling in marketing research", Journal of the Academy of Marketing Science, Vol. 40, No. 3, pp. 414-433.

Harrison-Walker, L.J., and Coppett, J.I. (2003), "Building bridges: the companycustomer relationship". Journal of Business To Business Marketing, Vol. 10, No. 4, pp. 49-72.

He, Y., Chen, Q., Lee, R. P., Wang, Y. and Pohlmann, A. (2017), “Consumers' Role 
Performance and Brand Identification: evidence from a Survey and a Longitudinal Field Experiment", Journal of Interactive Marketing, Vol. 38, No. 2, pp. 1-11.

Holbrook, M. B. and Batra, R. (1987), "Assessing the role of emotions as mediators of consumer responses to advertising". Journal of Consumer Research, Vol. 14, No. 3, pp. 404-420.

Holbrook, M.B. and Hirschman, E.C. (1982), "The experiential aspects of consumption: consumer fantasies, feelings, and fun", Journal of Consumer Research, Vol. 9, No. 2, pp. 132-140.

Hur, W.-M., Kim, M. and Kim, H. (2014), “The role of brand trust in male customers' relationship to luxury brands". Psychological Reports, Vol. 114, No. 2, pp. 609 624.

Jacoby, J. and Chestnut, R.W. (1978). Brand Loyalty Measurement and Management. New York: Wiley.

Jones, T. and Taylor, S. F. (2007), “The conceptual domain of service loyalty: how many dimensions?", Journal of Services Marketing, Vol. 21, No. 1, pp. 36-51.

Johnson, M.D., Herrmann, A.and Huber, F. (2006), "The evolution of loyalty intentions", Journal of Marketing, Vol. 70, No. 2, pp. 122-132.

Kabiraj, S. and Shanmugan, J. (2010), "Development of a conceptual framework for brand loyalty: a Euro-Mediterranean perspective". Journal of Brand Management, Vol. 18, No. 4, pp. 285-299.

Kandampully, J., Zhang, T. and Bilgihan, A.(2015), "Customer loyalty: a review and future directions with a special focus on the hospitality industry", International Journal of Contemporary Hospitality Management, Vol. 27, No. 3, pp. 379-414.

Keller, K. L. (2013). "Strategic Brand Management: Building, Measuring, and Managing Brand Equity”, Essex, England: Pearson Education.

Keller, K. L. and Richey, K. (2003). Strategic Brand Management. Upper Saddle River, New Jersey: Pearson Education.

Lane, V. and Jacobson, R. (1995), "Stock market reactions to brand extension announcements: the effects of brand attitude and familiarity". Journal of Marketing, Vol. 59, No. 1, pp. 63-77.

La, S. and Choi, B. (2012), "The role of customer affection and trust in loyalty rebuilding after service failure and recovery". The Service Industries Journal, Vol. 32, No. 1, pp. 105-125.

Lam, S.K., Ahearne, M.and Schillewaert, N. (2011), “A multinational examination of the symbolic-instrumental framework of consumer-brand identification", Journal of International Business Studies, Vol. 43, No. 3, pp. 306-331.

Lam, S.K., Ahearne, M., Mullins, R., Hayati, B. and Schillewaert, N. (2013), 
"Exploring the dynamics of antecedents to consumer-brand identification with a new brand", Journal of the Academy of Marketing Science, Vol. 41, No. 2, pp. 234-252.

Laroche, M., Habibi, M.R., Richard, M.O. and Sankaranarayanan, R. (2012), "The effects of social media based brand communities on brand community markers, value creation practices, brand trust and brand loyalty". Computers in Human Behavior, Vol. 28, No. 5, pp. 1755-1767.

Liu, F., Li, J., Mizerski, D. and Soh, H. (2012), "Self-congruity, brand attitude, and brand loyalty: a study on luxury brands", European Journal of Marketing, Vol. 46, No. 7/8, pp. 922-937.

Loureiro, S.M.C., Ruediger, K.H. and Demetris, V. (2012). "Brand emotional connection and loyalty". Journal of Brand Management, Vol. 20, No. 1, pp. 115 .

Mathwick, C., Wiertz, C.and De Ruyter, K. (2008), "Social capital production in a virtual P3 community", Journal of Consumer Research, Vol. 34, No. 6, pp. 832849.

Maxian, W., Bradley, S.D., Wise, W. and Toulouse, E.N. (2013), "Brand love is in the heart: Physiological responding to advertised brands". Psychology \& Marketing, Vol. 30, No. 6, pp. 469-478.

Ministry of Interior, T. (2016). Taiwan's Population analysis in Year 2015. Taiwan: Ministry of Interior, Taiwan, R.O.C. Retrieved from http://sowf.moi.gov.tw/stat/year/list.htm.

Morgan, R.M. and Hunt, S.D. (1994), "The commitment-trust theory of relationship marketing". Journal of Marketing, Vol. 58, No. 3, pp. 20-38.

Nunnally, J.C. (1978), Psychometric Theory, McGraw-Hill, New York.

Nusair, K., Parsa, HG and Cobanoglu, C. (2011), "Building a model of commitment for Generation Y: an empirical study on e-travel retailers", Tourism Management, Vol. 32, No. 4, pp. 833-843.

O'Loughlin, C. and Coenders, G. (2004), "Estimation of the european customer satisfaction index: maximum likelihood versus partial least squares. application to postal services", Total Quality Management and Business Excellence, Vol. 15, No. 9-10, pp. 1231-1255.

Odin, Y., Odin, N.and Valette-Florence, P. (2001), "Conceptual and operational aspects of brand loyalty: an empirical investigation", Journal of Business Research, Vol. 53, No. 2, pp. 75-84.

Oliver, R.L. (1999), “Whence consumer loyalty?”, Journal of Marketing, Vol. 63, No. special issue, pp. 33-44.

Oliver, R.L. (2010), Satisfaction: A Behavioral Perspective on the Consumer(2nd edn.), 
ME Sharpe, Armonk, New York.

Olsen, S.O., Tudoran, A.A., Brunsø, K. and Verbeke, W.(2013), "Extending the prevalent consumer loyalty modelling: the role of habit strength", European Journal of Marketing, Vol. 47, No. 1/2, pp. 303-323.

Payne, A.F., Storbacka, K. and Frow, P. (2008), "Managing the co-creation of value". Journal of the Academy of Marketing Science, Vol. 36, No. 1, pp. 83-96.

Pine II, B.J. and Gilmore, J.H. (2011), The Experience Economy, Harvard Business Press, Boston, MA.

Podsakoff, P. M., MacKenzie, S. B., Lee, J.-Y. and Podsakoff, N. P. (2003), “Common method biases in behavioral research: A critical review of the literature and recommended remedies", Journal of Applied Psychology, Vol. 88, No. 5, pp. 879-903.

Podsakoff, P. M. and Organ, D. W. (1986), "Self-reports in organizational research: Problems and prospects", Journal of Management, Vol. 12, No. 4, pp. 531-544.

Rauschnabel, P.A. and Ahuvia, A.C.(2014), "You're so lovable: anthropomorphism and brand love", Journal of Brand Management, Vol. 21, No. 5, pp. 372-395.

Rindfleisch, A., Burroughs, J.E.and Wong, N. (2009), "The safety of objects: materialism, existential insecurity, and brand connection", Journal of Consumer Research, Vol. 36, No. 1, pp. 1-16.

Ringle, C.M., Wende, S.and Will, S. (2005), SmartPLS 2.0 (M3), Beta, Hamburg, http://www.smartpls.de.

Schmitt, B. (2009), "The concept of brand experience", Journal of Brand Management, Vol. 16, No. 7, pp. 417-419.

Schmitt, B.(2013), "The consumer psychology of customer-brand relationships: extending the AA Relationship model”, Journal of Consumer Psychology, Vol. 23, No. 2, pp. 249-252.

Schmitt, B. and Rogers, D.L. (2008), Handbook on Brand and Experience Management, Edward Elgar Publishing, UK.

Schmitt, B.H. (1999), "Experiential marketing”, Journal of Marketing Management, Vol. 15, No. 1-3, pp. 53-67.

Shimp, T.A. and Madden, T.J. (1988), "Consumer-object relations: a conceptual framework based analogously on Sternberg's triangular theory of love", Advances in Consumer Research, Vol. 15, No. 1, pp. 163-168.

Sirdeshmukh, D., Singh, J.and Sabol, B. (2002), "Consumer trust, value, and loyalty in relational exchanges", Journal of Marketing, Vol. 66, No. 1, pp. 15-37.

Solomon, M. R. (2014). Consumer Behavior: Buying, Having, and Being (Vol. 10): Prentice Hall Engelwood Cliffs, NJ, USA.

Sternberg, R.J. (1986), “A triangular theory of love”, Psychological Review, Vol. 93, 
No. 2, pp. 119-135.

Stokburger-Sauer, N., Ratneshwar, S.and Sen, S. (2012), "Drivers of consumer-brand identification", International Journal of Research in Marketing, Vol. 29, No. 4, pp. 406-418.

Thomson, M., MacInnis, D.J.and Park, C.W. (2005), "The ties that bind: measuring the strength of consumers' emotional attachments to brands", Journal of Consumer Psychology, Vol. 15, No. 1, pp. 77-91.

Tuskej, U., Golob, U.and Podnar, K. (2013), "The role of consumer-brand identification in building brand relationships", Journal of Business Research,Vol. 66, No. 1, pp. 53-59.

Vinzi, V. E., Chin, W. W., Henseler, J. and Wang, H. (2010), Handbook of Partial Least Squares: Concepts, Methods and Applications, Springer, New York.

Vlachos, P.A. and Tsamakos, A.(2011), "Corporate social responsibility: attributions, loyalty and the mediating role of trust", Journal of the Academy of Marketing Science, Vol. 37, No. 2, pp. 170-180.

Whang, Y.O., Allen, J., Sahoury, N. and Zhang, H. (2004), "Falling in love with a product: the structure of a romantic consumer-product relationship", Advances in Consumer Research, Vol. 31, No. 1, pp. 320-327.

Wold, H. (1974), "Causal flows with latent variables: partings of the ways in the light of NIPALS modelling”, European Economic Review, Vol. 5, No. 1, pp. 67-86.

Zaichkowsky, J.L. (1985), "Measuring the involvement construct", Journal of Consumer Research, Vol. 12, No. 3, pp. 341-352.

Zboja, J.J. and oorhees, C.M. (2006), "The impact of brand trust and satisfaction on retailer repurchase intentions", Journal of Services Marketing, Vol. 20, No. 6, pp. 381-390. 
Appendix 1.The brand resonance model (Keller, 2013)

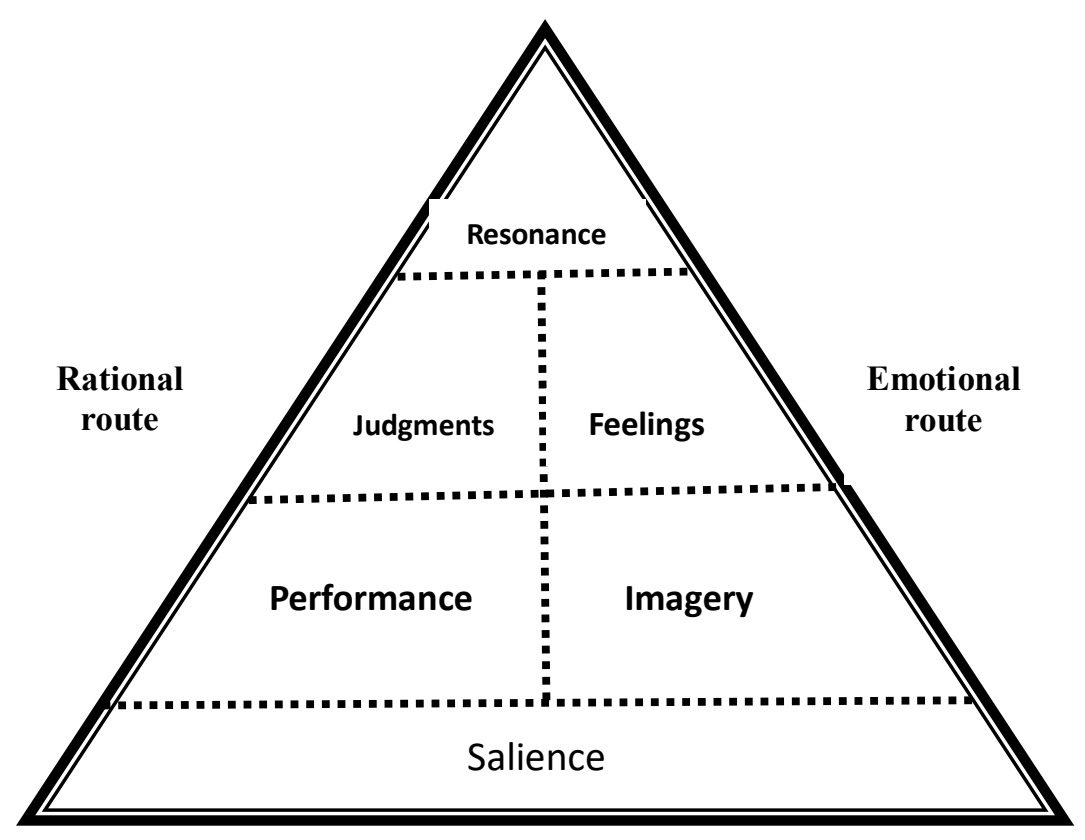

Notes: Salience includes those dimensions, such as category identification, awareness; resonance includes those, such as loyalty, attachment, community and engagement. 
Appendix 2.Operational definitions, measurement items and sources

\begin{tabular}{|c|c|c|c|c|}
\hline $\begin{array}{l}\text { Constructs/ } \\
\text { Dimensions }\end{array}$ & Operational definitions & $\begin{array}{c}\text { Item } \\
\# \\
\end{array}$ & Measurement items & Sources \\
\hline \multirow{3}{*}{$\begin{array}{l}\text { Sensory } \\
\text { Experience }\end{array}$} & Subjective, internal consumer responses & BES1 & This brand makes a strong impression on my visual senses or other senses. & Brakus et al., \\
\hline & (sensations and intelligence) and & BES2 & I find this brand interesting in a sensory way. & 2009 \\
\hline & behavioral responses evoked by brand- & BES3 & This brand does not appeal to my senses.* & \\
\hline Intellectual & related stimuli that are part of a brand's & BEI1 & I engage in a lot of thinking when I encounter this brand. & \\
\hline \multirow[t]{2}{*}{ Experience } & design and identity, packaging, & BEI2 & This brand does not make me think.* & \\
\hline & communications, and environments. & BEI3 & This brand stimulates my curiosity and problem solving. & \\
\hline \multicolumn{2}{|l|}{ Behavioral } & BEB1 & I engage in physical actions and behavioral when I use this brand. & \\
\hline \multirow[t]{2}{*}{ Experience } & & BEB2 & This brand results in bodily experiences. & \\
\hline & & BEB3 & This brand is not action-oriented.* & \\
\hline \multirow[t]{5}{*}{ Brand Love } & The degree of passionate emotional & BLV5 & This brand makes me very happy. & Carroll and \\
\hline & attachment a satisfied consumer has for a & BLV6 & I love this brand. & Ahuvia, 2006 \\
\hline & particular trade name. It includes passion & BLV8 & This brand is a pure delight. & \\
\hline & for the brand, attachment to the brand, & BLV9 & I am passionate about this brand. & \\
\hline & $\begin{array}{l}\text { positive evaluation of the brand, positive } \\
\text { emotions in response to the brand, and } \\
\text { declarations of love for the brand. }\end{array}$ & BLV10 & I am very attached to this brand. & \\
\hline \multirow{8}{*}{$\begin{array}{l}\text { Brand } \\
\text { Trust }\end{array}$} & It concerns the perception that the brand & BTR2 & This is a brand name that meets my expectations. & Delgado- \\
\hline & can fulfill or satisfy consumers. needs. It & BTR3 & I feel confidence in this brand's name. & Ballester, E., et \\
\hline & is related to the individual's belief that & BTR4 & This is a brand never disappoints me. & al., 2003 \\
\hline & $\begin{array}{l}\text { the brand accomplishes its value } \\
\text { promise. }\end{array}$ & BTR5 & This brand guarantees satisfaction. & \\
\hline & It reflects an emotional security on the & BTI1 & This brand would be honest and sincere in addressing my concerns. & \\
\hline & part of individuals, and describes the & BTI2 & This brand would make any effort to satisfy me. & \\
\hline & aspect of a belief that goes beyond the & BTI3 & I could rely on this brand to solve the problem. & \\
\hline & $\begin{array}{l}\text { available evidence to make individuals } \\
\text { feel, with assurance, that the brand will } \\
\text { be responsible and caring despite the } \\
\text { vicissitudes of future problematic } \\
\text { situations and circumstances with the } \\
\text { consumption of the product. }\end{array}$ & BTI5 & $\begin{array}{l}\text { This brand would compensate me in some way for the problem with mobile } \\
\text { phone. }\end{array}$ & \\
\hline \multirow{2}{*}{$\begin{array}{l}\text { Behavioral } \\
\text { Loyalty }\end{array}$} & Customers' continuous purchase of the & BLY2 & Overall, I buy this brand most often. & Chaudhuri and \\
\hline & brand, as well as their repeated and & BLY3 & I'll tell other people how good this brand is. & Holbrook, 2001; \\
\hline
\end{tabular}


extended purchase intention.

Customers' psychological commitment

to the brand, and their belief that the

brand is unique.

Loyalty

A consumer's psychological state of

perceiving, feeling, and valuing his or

her belongingness with a brand.
BLY4 I'll recommend this brand to other people.

ALY1 I identify with this brand very much.

ALY2 I'm willing to pay a higher price to buy this brand.

ALY3 If this brand is out of stock, I'll wait and refuse any substitutes.

BI3 When someone praised this brand, it feels like a personal compliment

BI4 I would experience an emotional loss if I had to stop using this brand.

BI5 I believe others respect me for my association with brand.

Notes: *denotes items that are reverse scored.

The construct, brand attachment, consists of two dimensions: self-brand congruency (SBC) and brand prominence (BP); Brand loyalty consists of two dimensions: behavioral and attitudinal.

Answer scale: $1=$ strongly disagree; $2=$ disagree; $3=$ no opinion; $4=$ agree; $5=$ strongly agree 
Appendix 3. Competing models to test the mediating effects of brand love and trust

\begin{tabular}{|c|c|c|c|c|}
\hline Model \# & Hypotheses & $\begin{array}{c}\text { Path } \\
\text { coefficients }\end{array}$ & $t$-value & Results \\
\hline \multirow[t]{6}{*}{ Model 1} & Sensory experience $\rightarrow$ Brand love & 039 & $5.44 * * *$ & Significant \\
\hline & Intellectual experience $\rightarrow$ Brand love & 0.21 & $3.15 * *$ & Significant \\
\hline & Behavioral experience $\rightarrow$ Brand love & 0.18 & $2.82 * *$ & Significant \\
\hline & Sensory experience $\rightarrow$ Brand trust & 0.37 & $5.13 * * *$ & Significant \\
\hline & Intellectual experience $\rightarrow$ Brand trust & 0.14 & 1.50 & $\begin{array}{l}\text { Non- } \\
\text { significant }\end{array}$ \\
\hline & Behavioral experience $\rightarrow$ Brand trust & 0.22 & $2.37 *$ & Significant \\
\hline \multirow[t]{6}{*}{ Model 2} & Sensory experience $\rightarrow$ Behavioral loyalty & 0.37 & $6.04 * * *$ & Significant \\
\hline & Sensory experience $\rightarrow$ Attitudinal loyalty & 0.30 & $6.55 * * *$ & Significant \\
\hline & Intellectual experience $\rightarrow$ Behavioral loyalty & 0.21 & $3.05 * *$ & Significant \\
\hline & Intellectual experience $\rightarrow$ Attitudinal loyalty & 0.17 & $2.53 *$ & Significant \\
\hline & Behavioral experience $\rightarrow$ Behavioral loyalty & 0.11 & 1.48 & $\begin{array}{l}\text { Non- } \\
\text { significant }\end{array}$ \\
\hline & Behavioral experience $\rightarrow$ Attitudinal loyalty & 0.12 & 1.71 & $\begin{array}{l}\text { Non- } \\
\text { significant }\end{array}$ \\
\hline \multirow[t]{4}{*}{ Model 3} & Brand love $\rightarrow$ Behavioral loyalty & 0.40 & $5.12 * * *$ & Significant \\
\hline & Brand love $\rightarrow$ Attitudinal loyalty & 0.38 & $4.59 * * *$ & Significant \\
\hline & Brand trust $\rightarrow$ Behavioral loyalty & 0.31 & $4.42 * * *$ & Significant \\
\hline & Brand trust $\rightarrow$ Attitudinal loyalty & 0.39 & $5.30 * * *$ & Significant \\
\hline \multirow[t]{10}{*}{ Model 4} & Sensory experience $\rightarrow$ Behavioral loyalty & 0.15 & $2.01 *$ & Significant \\
\hline & Sensory experience $\rightarrow$ Attitudinal loyalty & 0.17 & $2.29 * *$ & Significant \\
\hline & Intellectual experience $\rightarrow$ Behavioral loyalty & 0.11 & 1.54 & $\begin{array}{l}\text { Non- } \\
\text { significant }\end{array}$ \\
\hline & Intellectual experience $\rightarrow$ Attitudinal loyalty & 0.07 & 1.09 & $\begin{array}{l}\text { Non- } \\
\text { significant }\end{array}$ \\
\hline & Behavioral experience $\rightarrow$ Behavioral loyalty & 0.01 & 0.10 & $\begin{array}{l}\text { Non- } \\
\text { significant }\end{array}$ \\
\hline & Behavioral experience $\rightarrow$ Attitudinal loyalty & -0.01 & 0.12 & $\begin{array}{l}\text { Non- } \\
\text { significant }\end{array}$ \\
\hline & Brand love $\rightarrow$ Behavioral loyalty & 0.31 & $3.64 * * *$ & Significant \\
\hline & Brand love $\rightarrow$ Attitudinal loyalty & 0.27 & $3.08 * *$ & Significant \\
\hline & Brand trust $\rightarrow$ Behavioral loyalty & 0.24 & $3.27 * *$ & Significant \\
\hline & Brand trust $\rightarrow$ Attitudinal loyalty & 0.33 & $4.84 * * *$ & Significant \\
\hline
\end{tabular}

